DOI https://doi.org/10.30525/978-9934-588-81-5-1.51

\title{
COMPARATIVE CHARACTERISTICS OF LABORATORY INDICATORS AS MARKERS OF SEPSIS
}

\author{
Fuss Yu. O. \\ $P h D$, \\ Department of surgery, \\ Regional hospital in Pustomyty, \\ Pustomyty, Lviv region, Ukraine \\ Voloboyeva A. O. \\ Department of Anesthesiology, \\ Communal 8th Municipal Clinical Hospital \\ Lviv, Ukraine
}

Early diagnosis of sepsis is a key point of effective therapy of this pathology. For early diagnosis of the development of septic process of any etiology also use laboratory criteria such as presepsin, procalcitonin, $\mathrm{C}$ reactive protein, tumor necrosis factor, interleukin -6. PCT and CRP are mostly used as markers for the diagnosis of sepsis, but they also have certain disadvantages $[1,2]$. PCT also increases under the influence of nonbacterial inflammation, such as trauma, surgery. The level of CRP may increase with a localized infectious process and does not always adequately reflect the severity of the infectious process. To date, the search for a highly sensitive indicator for early diagnosis of sepsis, assessment of severity and prognosis continues.

In some clinics, the determination of cholesterol levels is used as a laboratory criterion for the septic process $[3,4]$. In this regard, the aim of the study is to study the informativeness of the dynamic determination of laboratory markers of sepsis - PCT, CRP and cholesterol [5].

Materials and methods. The study involved 153 patients who were treated at PRH. The inclusion criteria were the presence of signs of severe sepsis in the patient with dysfunction of two or more systems. Patients were in the ICU department with the following pathology: abdominal sepsis - 55 (36\%), osteomyelitis - 52 (34\%), cryptogenic sepsis - 46 (30\%). All patients on admission and in the dynamics were determined by PKT, CRP and cholesterol, as well as microbiological studies.

Results. All patients were divided into two groups depending on the completion of the disease: I - group in which treatment did not work and 
ended in death; II - group - patients with a positive effect from the prescribed treatment.

The level of PKT on the 1st day in both groups was increased and amounted to: in group I $-3.7 \mathrm{ng} / \mathrm{ml}$, in group II $-1.7 \mathrm{ng} / \mathrm{ml}$. At 5-6 days, this figure was: in group I $-4.6 \mathrm{ng} / \mathrm{ml}$, in group II $-0.3 \mathrm{ng} / \mathrm{ml}$. The level of PCT at the last stage of treatment in the ICU was statistically higher in the first screw $-5.1 \mathrm{ng} / \mathrm{ml}$ compared to group II $-0.2 \mathrm{ng} / \mathrm{ml}$.

On the 1st day of treatment in both groups CRP was high: in group I $121.5 \mathrm{ml} / 1$, in group II $-99.9 \mathrm{ml} / 1$. for 5-6 days the level of CRP in group I increased, in group II - decreased. At the same time, the level of CRP on the 5th-6th day was statistically significantly higher in group I $-184 \mathrm{ml} / 1$ than in group II $-45.0 \mathrm{ml} / 1$. on the 10 th day there was a significant decrease in CRP in patients of group II.

On day 1, no significant differences in cholesterol levels were observed between the two groups. Cholesterol levels were reduced for 5-6 days: in group I it decreased from 4.02 to $3.25 \mathrm{mmol} / \mathrm{l}$; in group II $-4.7 \mathrm{mmol} / 1$ to $3.77 \mathrm{mmol} / 1$. On the 10th day of treatment, the cholesterol level in group II did not change statistically significantly and amounted to $4.5 \mathrm{mmol} / \mathrm{l}$, and in group I there was a further decrease in cholesterol levels.

Conclusions.

1. Upon admission to the ICU, patients with sepsis and MOD had an elevated PCT. Its gradual decrease on the 5th-6th day is a favorable prognostic sign. Maintaining a high concentration or re-increase in PKT is a sign of further development of the septic process.

2. The level of CRP in patients with sepsis and MOD on admission was sharply increased. Decreased CRP is a favorable prognostic sign. 3. In patients with septic process on the 5-6th day of admission, a decrease in cholesterol was observed. Further reduction of this marker is a prognostically unfavorable sign of the disease.

4. The use of these indicators (PCT, CRP, cholesterol) at the level of assessment of clinical criteria and blood tests, provides monitoring of the inflammatory response, early diagnosis of sepsis, disease prognosis.

\section{References:}

1. Mann EA, Baun MM, Meininger JC, Wade CE. Comparison of mortality associated with sepsis in the burn, trauma, and general intensive care unit patient: a systematic review of the literature. Shock. 2012 Jan;37(1):4-16. doi: 10.1097/SHK.0b013e318237d6bf.

2. Jeschke MG, Chinkes DL, Finnerty CC, Kulp G, SumanOE, Norbury WB, et al. Pathophysiologic response to severe burn injury. Ann Surg. 2008 Sep;248(3):387-401. doi: 10.1097/SLA.0b013e3181856241 
3. Cree MG, Wolfe RR. Postburn trauma insulin resistance and fat metabolism. Am J Physiol Endocrinol Metab. 2008 Jan;294(1):E1-9. doi: 10.1152/ajpendo.00562.2007

4. Hart DW, Wolf SE, Mlcak R, Chinkes DL, Ramzy PI, Obeng MK, et al. Persistence of muscle catabolism after severe burn. Surgery. 2000 Aug;128(2):312-9.

5. Mochizuki H, Trocki O, Dominioni L, Brackett KA, Joffe SN, Alexander JW. Mechanism of prevention of postburn hypermetabolism and catabolism by early enteral feeding. Ann Surg. 1984 Sep;200(3):297-310.

DOI https://doi.org/10.30525/978-9934-588-81-5-1.52

\title{
РОЗПОВСЮДЖЕНІСТЬ РЕЗИСТЕНТНОСТІ ДО АЦЕТИЛСАЛІЦИЛОВОЇ КИСЛОТИ У ХВОРИХ НА АРТЕРІАЛЬНУ ГІПЕРТЕНЗІЮ
}

\author{
Черниловський А. В. \\ кандидат медичних наук, \\ асистент кафедри сімейної медищини \\ факультету післядипломної освіти \\ Дніпропетровська медична академія \\ Axe 6. A. \\ лікар загальної практики сімейної медицини \\ Комунальне некомериійне підприємство \\ «Дніпропетровський центр первинної медико-санітарної допомоги» \\ Дніпропетровської міської ради \\ м. Дніпро, Україна

\section{Аніщенко М. I.} \\ лікар загальної практики сімейної медицини \\ Комунальне некомериійне підприємство «Центр первинної \\ медико-санітарної допомоги» Богданівської сільської ради \\ Дніпропетровської області» \\ м. Павлоград, Дніпропетровська область, Украӥна
}

Актуальність: збільшення випадків резистентності до ацетилсаліцилової кислоти у пацієнтів хворих на артеріальну гіпертензію. 